CLINICAL STUDY

\title{
Enhancement of the peripheral sensitivity to growth hormone in adults with GH deficiency
}

\author{
G Aimaretti, G Fanciulli ${ }^{1}$, S Bellone, M Maccario, E Arvat, G Delitala ${ }^{1}$, F Camanni and E Ghigo \\ Division of Endocrinology, Department of Internal Medicine, University of Turin, Italy and ${ }^{1}$ Division of Internal Medicine, University of Sassari, Italy \\ (Correspondence should be addressed to E Ghigo, Divisione di Endocrinologia, Ospedale Molinette, C.so Dogliotti 14, 10126 Torino, Italy; \\ Email: ezio.ghigo@unito.it)
}

\begin{abstract}
Objective: Adults with severe GH deficiency (GHD) need recombinant human growth hormone (rhGH) replacement to restore body composition, structure functions and metabolic abnormalities. The optimal rhGH dose for replacement has been progressively reduced to avoid side effects. The aim of the present study was to define the minimal rhGH dose able to increase both IGF-I and IGF binding protein (BP)-3 levels in GHD and to verify the possible change in GH sensitivity.

Design and patients: To this goal, we studied the effect of 4-day treatment with 3 rhGH doses $(1.25,2.5$ and $5.0 \mu \mathrm{g} / \mathrm{kg} /$ day) on IGF-I and IGFBP-3 levels in 25 panhypopituitary adults with severe GHD (12 males and 13 females, age: $44.5 \pm 3.0$ years, body mass index (BMI): $27.0 \pm 0.9 \mathrm{~kg} / \mathrm{m}^{2}$ ) and 21 normal young adult volunteers (NV, 12 males and 9 females, age: $30.5 \pm 2.0$ years, BMI: $20.8 \pm 0.5 \mathrm{~kg} / \mathrm{m}^{2}$ ).

Results: Basal IGF-I and IGFBP-3 levels in GHD were lower $(P<0.001)$ than in NV. In NV the $1.25 \mu \mathrm{g} / \mathrm{kg}$ dose of rhGH did not modify IGF-I levels. The dose of $2.5 \mu \mathrm{g} / \mathrm{kg} \mathrm{rhGH}$ significantly increased IGF-I levels in men $(P<0.001)$ but not in women, while the $5.0 \mu \mathrm{g} / \mathrm{kg}$ dose increased IGF-I levels in both sexes $(P<0.001)$. IGFBP-3 levels were not modified by any of the administered rhGH doses. In GHD patients, all rhGH doses increased IGF-I levels $12 \mathrm{~h}$ after both the first $(P<0.01)$ and the fourth rhGH dose $(P<0.001)$. At the end of treatment percentage increases in IGF-I were higher $(P<0.001)$ in GHD patients than in NV. In contrast with NV, in GHD patients the IGF-I response to short-term stimulation with rhGH was independent of gender. Moreover, GHD patients showed increases in IGFBP-3 after the fourth administration of both 2.5 and $5.0 \mu \mathrm{g} / \mathrm{kg} \mathrm{rhGH}$. Conclusion: The results of the present study demonstrate that the minimal rhGH dose able to increase IGF-I and IGFBP-3 levels in GHD patients is lower than in normal subjects, at least after a very short treatment. This evidence suggests an enhanced peripheral GH sensitivity in GH deprivation.
\end{abstract}

European Journal of Endocrinology 145 267-272

\section{Introduction}

The activity of the growth hormone/insulin-like growth factor-I (GH/IGF-I) axis has a major role in promoting growth, but also plays a key role in protein, glucose and lipid metabolism, influencing body composition and structure function (1). In adulthood, the metabolic actions of the GH/IGF-I axis take place at secretory levels which are markedly lower than those needed to promote growth (2). IGF-I and IGF binding protein-3 (IGFBP-3) levels reflect the GH status (3), although IGF-I synthesis and release are also under important regulation by nutrition (4).

IGF-I concentrations have been shown to be positively related to GH secretion in normal, acromegalic, and GH deficient subjects and IGF-I measurement is widely used to assess disease activity in acromegaly (1) as well as to screen patients with suspected GH deficiency (GHD) (1, 3). Although the reliability of the IGF-I measurement for the diagnosis of GHD in adults has been questioned by many authors (5-8), there is agreement that it is the best parameter for monitoring the appropriate recombinant human growth hormone (rhGH) replacement therapy $(9-11)$.

Adults with severe GHD show alterations in body composition, structure function and metabolism that are reversed by rhGH replacement treatment $(9,11-$ 18). The rhGH dose for replacement therapy in adults with severe GHD has been progressively reduced to minimise side effects $(10,11,15,19,20)$. As alluded to before, IGF-I is the best biochemical marker for monitoring GH replacement and IGF-I values should be kept in the age-related normal range $(9,11)$.

The aim of the present study was to define the minimal rhGH dose able to increase IGF-I and IGFBP-3 levels in $\mathrm{GH}$ deficiency and to verify the possible change 
in GH sensitivity. To this goal, we studied the effects of 4-day treatments with 3 low rhGH doses $(1.25,2.5$ and $5.0 \mu \mathrm{g} / \mathrm{kg} /$ day) on IGF-I and IGFBP-3 levels in adults with severe GHD. These results were compared with those recorded in normal subjects in whom we have previously shown that IGF-I and IGFBP-3 responses to rhGH are dose- and sex-dependent (21).

\section{Subjects and methods}

Twenty-five panhypopituitary adults with severe GH deficiency (GHD, 12 males and 13 females, age: $44.5 \pm$ 3.0 years, body mass index (BMI): $27.0 \pm 0.9 \mathrm{~kg} / \mathrm{m}^{2}$ ) were studied. Seventeen acquired panhypopituitarism after pituitary surgery or radiotherapy. All patients were on optimized replacement therapy other than $\mathrm{GH}$ for at least three months. As controls, 21 normal young adult volunteers (NV, 12 males and 9 females, age: $30.5 \pm 2.0$ years, BMI: $20.8 \pm 0.5 \mathrm{~kg} / \mathrm{m}^{2}$ ) were studied. None of the female volunteers received hormonal contraception and the study was performed in the early follicular phase. An independent Ethics Committee approved the study and all subjects gave informed consent to enter the study.

Severe GHD has been demonstrated in all patients by showing a GH peak $<3 \mu \mathrm{g} / \mathrm{l}$ after an insulin tolerance test $(6,11)$ and/or $<9 \mu \mathrm{g} / \mathrm{l}$ after $\mathrm{GH}$ releasing hormone $(\mathrm{GHRH})+$ arginine test $(11,22)$.

GHD patients and NV underwent 3 treatments with $\mathrm{rhGH}$ at doses of $1.25 \mu \mathrm{g} / \mathrm{kg} /$ day $(n=14$ and 21 respectively), $2.5 \mu \mathrm{g} / \mathrm{kg} /$ day $(n=15$ and 21 respectively) or $5 \mu \mathrm{g} / \mathrm{kg} /$ day $(n=14$ and 21 respectively). The rhGH doses (Norditropin; Novo-Nordisk, Copenhagen, Denmark and Genotropin; Pharmacia PH, Stockholm, Sweden; vials $4 \mathrm{IU}=1.33 \mathrm{mg}$ in $1 \mathrm{ml}$ ) were given subcutaneously every evening at $2100 \mathrm{~h}$ for 4 days. Tests were performed in random order at least one month apart. Blood samples for IGF-I, IGFBP-3, insulin and glucose levels were drawn basally and $12 \mathrm{~h}$ after the first and the last rhGH administration (i.e. $84 \mathrm{~h}$ after the first rhGH administration).

Serum IGF-I $(\mu \mathrm{g} / \mathrm{l})$ was measured in duplicate by RIA (Nicholls Institute Diagnostic, San Juan Capistrano, CA,
USA). The sensitivity of the assay was $0.25 \mu \mathrm{g} / \mathrm{l}$. The inter- and intra-assay coefficients of variation were $5.2-8.4 \%$ and $2.4-3.0 \%$ respectively. Serum IGFBP-3 $(\mathrm{mg} / \mathrm{l})$ was measured in duplicate by RIA (Nicholls Institute Diagnostic). The sensitivity of the assay was $0.25 \mathrm{ng} / \mathrm{ml}$. The inter- and intra-assay coefficients of variation were $5.3-6.3 \%$ and $3.4-8.0 \%$ respectively. Serum insulin $(\mu \mathrm{U} / \mathrm{l})$ was measured in duplicate by IRMA (Sorin, Saluggia, Italy). The sensitivity of the assay was $2.5 \mu \mathrm{U} / \mathrm{l}$. The inter- and intra-assay coefficients of variation were $6.5-15.0 \%$ and $4.5-$ $13.4 \%$ respectively. Plasma glucose $(\mathrm{mg} / \mathrm{dl})$ was measured by the glucose-oxidase colorimetric method (Menarini Diagnostics, Firenze, Italy).

Data are expressed as means \pm S.E.M. of absolute and percentage changes. The statistical analysis of the data was carried out by paired and unpaired Student's $t$-test and ANOVA where appropriate.

\section{Results}

\section{Normal volunteers (NV)}

Mean basal IGF-I and IGFBP-3 levels were 212.1 \pm $5.6 \mu \mathrm{g} / \mathrm{l}$ and $2.9 \pm 0.1 \mathrm{mg} / \mathrm{l}$ respectively and did not differ significantly among various testing sessions.

The dose of $1.25 \mu \mathrm{g} / \mathrm{kg}$ rhGH failed to modify IGF-I levels at any time, while these were significantly increased $12 \mathrm{~h}$ after the first and the fourth administration of $2.5 \mu \mathrm{g} / \mathrm{kg} \mathrm{rhGH}(220.9 \pm 12.8$ and $242.9 \pm 13.4$, respectively, vs basal $205.3 \pm 14.8 \mu \mathrm{g} / \mathrm{l} ; P<0.001)$ and $5.0 \mu \mathrm{g} / \mathrm{kg} \mathrm{rhGH}(272.2 \pm 16.1$ and $301.7 \pm 17.6$, respectively, vs basal $230.4 \pm 16.1 \mu \mathrm{g} / \mathrm{l} ; \quad P<0.001)$ showing a clear dose-response relationship $(P<0.001)$ (Fig. 1 and see also Fig. 3). When the data were examined by gender, the dose of $2.5 \mu \mathrm{g} / \mathrm{kg}$ rhGH was found significantly to stimulate IGF-I levels in men $(P<0.001)$ but not in women (Table 1$)$.

None of the rhGH doses $(1.25,2.5$ and $5.0 \mu \mathrm{g} / \mathrm{kg})$ effected a change in IGFBP-3 levels (Fig. 2). Glucose and insulin levels were not modified at any time (data not reported).

Table 1 IGF-I delta $(\Delta)$ absolute $(\mu \mathrm{g} / \mathrm{L})$ and delta $(\Delta)$ percent increase $84 \mathrm{~h}$ after the first administration of different rhGH doses in 21 normal volunteers and in 25 patients with $\mathrm{GH}$ deficiency.

\begin{tabular}{lcccccc}
\hline & \multicolumn{3}{c}{ Men } & & \multicolumn{2}{c}{ Women } \\
\cline { 2 - 3 } rhGH dose $(\mu \mathrm{g} / \mathrm{kg})$ & $\Delta$ absolute & $\Delta$ percent & $P$-value & & $\Delta$ absolute & $\Delta$ percent $^{*} P$-value \\
\hline Normal volunteers & $9.6 \pm 5.4$ & $5.4 \pm 2.9$ & $\mathrm{NS}$ & $8.5 \pm 4.2$ & $2.5 \pm 2.1$ & $\mathrm{NS}$ \\
1.25 & $49.8 \pm 11.8$ & $38.0 \pm 11.8$ & 0.001 & $21.3 \pm 10.7$ & $9.3 \pm 4.7$ & $\mathrm{NS}$ \\
2.5 & $74.9 \pm 21.6$ & $53.5 \pm 16.4$ & 0.001 & $27.0 \pm 9.0$ & $24.4 \pm 5.0$ & 0.001 \\
5.0 & $66.5 \pm 16.6$ & $116.4 \pm 30.6$ & 0.001 & $49.3 \pm 12.1$ & $88.3 \pm 31.2$ & 0.001 \\
GH deficiency & $77.6 \pm 21.0$ & $125.4 \pm 49.0$ & 0.001 & $42.6 \pm 16.4$ & $85.7 \pm 20.7$ & 0.001 \\
1.25 & $66.0 \pm 18.9$ & $147.7 \pm 44.0$ & 0.001 & $56.7 \pm 9.4$ & $139.0 \pm 24.1$ & 0.001 \\
2.5 & & & & & &
\end{tabular}

${ }^{\star} P$-value vs baseline; NS, not significant. 

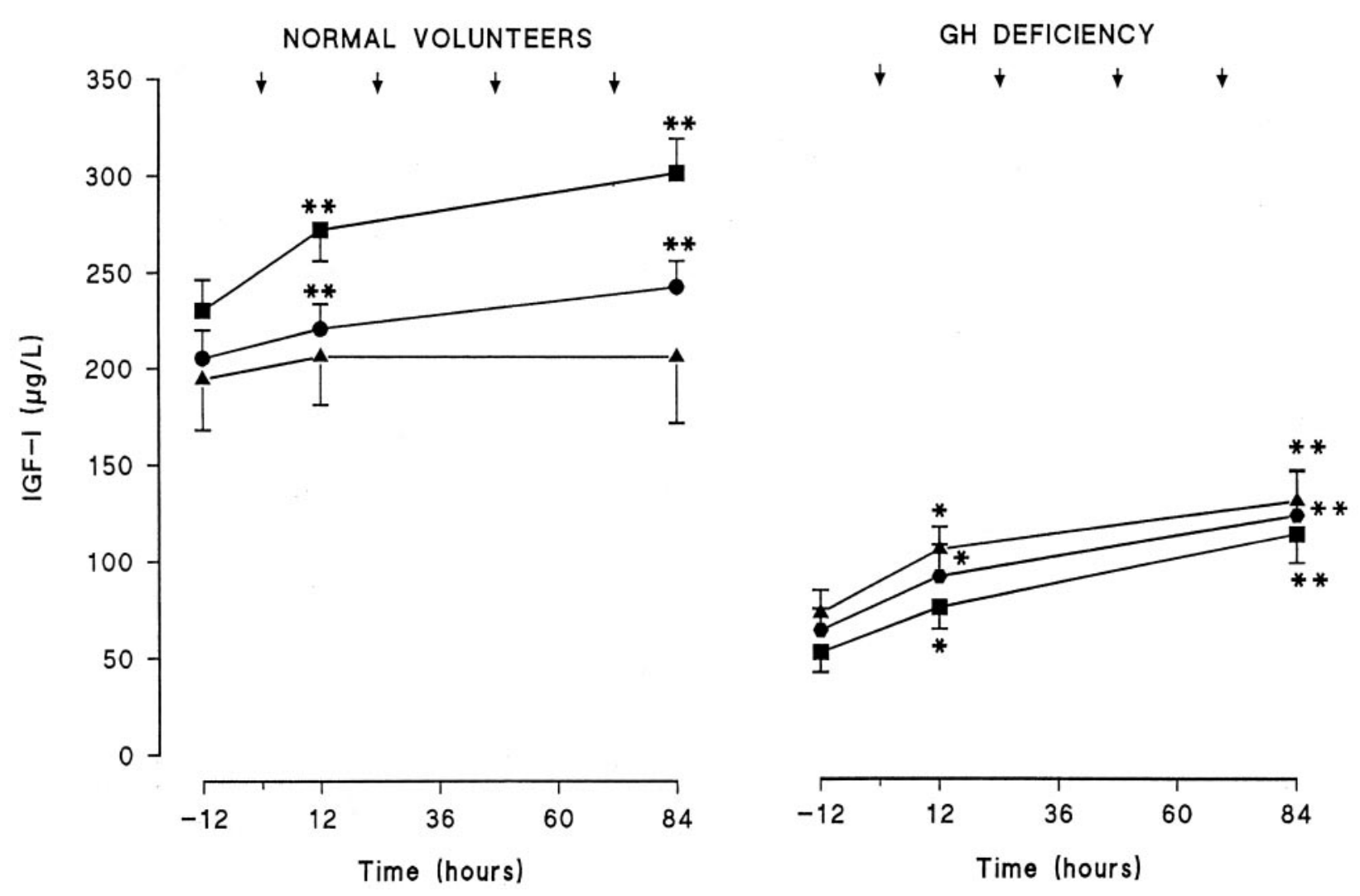

Figure 1 Effect of 4-day treatment with $3 \mathrm{rhGH}$ doses $(\boldsymbol{\Lambda}, 1.25 \mu \mathrm{g} / \mathrm{kg} / \mathrm{day} ; \boldsymbol{\bullet}, 2.5 \mu \mathrm{g} / \mathrm{kg} / \mathrm{day} ; \mathbf{\square}, 5.0 \mu \mathrm{g} / \mathrm{kg} / \mathrm{day})$ on IGF-I levels (mean \pm S.E.) in 21 normal volunteers and 25 patients with severe GH deficiency. ${ }^{\star} P<0.01,{ }^{\star \star} P<0.001$ vs baseline; $\downarrow$ rhGH administration.

\section{Patients with GH deficiency (GHD)}

Mean basal IGF-I and IGFBP-3 levels $(64.4 \pm 8.7 \mu \mathrm{g} / \mathrm{l}$ and $1.6 \pm 0.2 \mathrm{mg} / \mathrm{l}$ respectively) in GHD patients did not differ significantly among various testing sessions and were clearly lower than those in NV $(P<0.001)$.

All rhGH doses $(1.25,2.5$ and $5.0 \mu \mathrm{g} / \mathrm{kg})$ increased IGF-I levels $12 \mathrm{~h}$ after both the first (105.0 $\pm 11.7 \mathrm{vs}$ $72.2 \pm 11.6,91.0 \pm 16.4$ vs $63.5 \pm 11.0$ and $75.2 \pm$ 11.0 vs $52.1 \pm 10.5 \mu \mathrm{g} / \mathrm{l}$ respectively, $P<0.01)$ and the fourth $(130.2 \pm 15.3,122.5 \pm 23.5$ and $112.8 \pm$ $15.0 \mu \mathrm{g} / \mathrm{l}$ respectively, $P<0.001) \mathrm{rhGH}$ dose, showing no dose-response relationship $(P=$ not significant $)$ (Fig. 1 and see also Fig. 3). At the end of treatment, the delta IGF-I percentage increases were clearly higher $(P<0.001)$ in GHD patients than in NV in response to all rhGH doses (Fig. 3 and Table 1).

In contrast with NV, no gender-related difference was found in the IGF-I response to rhGH in GHD patients. In fact, even the lowest rhGH dose, i.e. $1.25 \mu \mathrm{g} / \mathrm{kg}$, elicited the same increase in IGF-I levels in GHD patients of both sexes $(P<0.001$ vs baseline) (Table 1$)$.

GHD patients also showed a significant increase in IGFBP-3 after the fourth administration of both 2.5 and $5.0 \mu \mathrm{g} / \mathrm{kg} \mathrm{rhGH}(2.4 \pm 0.2$ vs $1.8 \pm 0.4$ and $2.0 \pm$ 0.2 vs $1.3 \pm 0.3 \mathrm{mg} / \mathrm{l}$ respectively, $P<0.05$ ) (Fig. 2).
Insulin and glucose levels were not modified by any rhGH dose (data not reported).

\section{Discussion}

The results of the present study demonstrate that, at least after very short-term treatment, the minimal rhGH dose able to increase IGF-I or IGFBP-3 levels is lower in GHD adults than in normal subjects, suggesting an enhanced GH sensitivity. Moreover, the mean IGF-I percentage increase after each rhGH dose administered was higher in GHD patients than in normal subjects.

The stimulatory effect of low rhGH doses (ranging from 2.5 to $5.0 \mu \mathrm{g} / \mathrm{kg} /$ day) on IGF-I levels in GHD adults has already been studied by other authors $(10,23)$ although it has never been compared with data in normal subjects. Our study shows that a rhGH dose as low as $1.25 \mu \mathrm{g} / \mathrm{kg} /$ day (that is about $0.00375 \mathrm{IU} / \mathrm{kg} / \mathrm{day}$ ) is able to stimulate IGF-I levels in severe GHD patients, although after very short-term treatment. This evidence does not imply that this dose is effective for optimal replacement; in fact, it has already been shown that the IGF-I response to rhGH is not strictly associated with protein anabolism (23) and clinical benefit (11, 

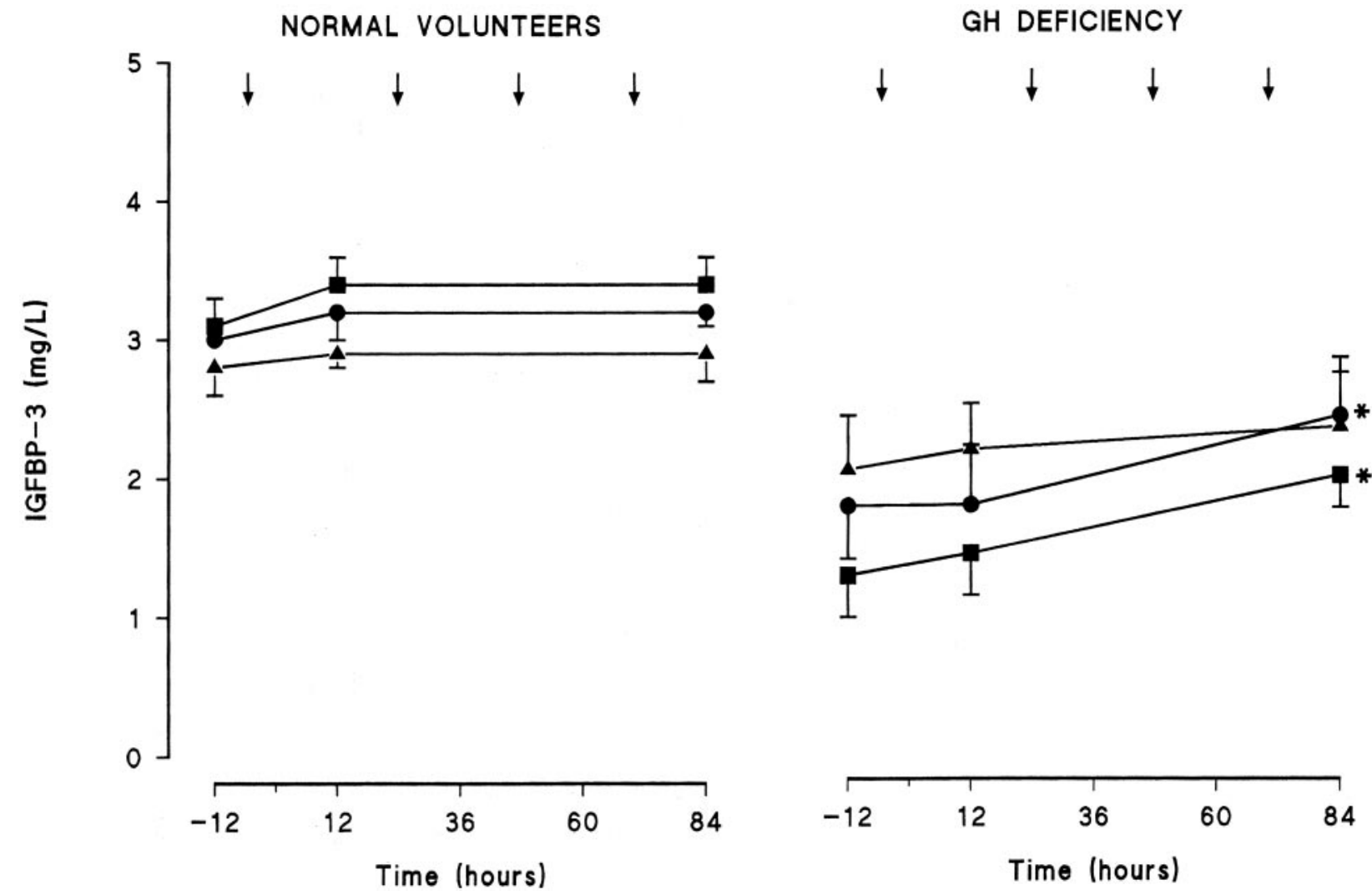

Figure 2 Effect of 4-day treatment with $3 \mathrm{rhGH}$ doses $(\boldsymbol{\Lambda}, 1.25 \mu \mathrm{g} / \mathrm{kg} /$ day; $\bullet, 2.5 \mu \mathrm{g} / \mathrm{kg} /$ day; $\mathbf{\square}, 5.0 \mu \mathrm{g} / \mathrm{kg} /$ day) on IGFBP-3 levels (mean \pm S.E.) in 21 normal volunteers and 25 patients with severe GH deficiency. ${ }^{\star} P<0.05$ vs baseline; $\downarrow$ rhGH administration.

20). Treatment did not show a dose-response relationship at variance with that recorded in normal subjects. This result agrees with the finding of a similar increase in IGF-I levels following a one-week treatment with either 2.0 or $3.3 \mu \mathrm{g} / \mathrm{kg} /$ day rhGH in hypopituitary adults (23). Interestingly, in those subjects a doseresponse relationship became apparent only after one month of treatment.

Thus, it is apparent from the present study that, at least at the beginning of $\mathrm{GH}$ replacement, patients with severe GHD show an enhanced GH sensitivity. It has been clearly shown that the GH-receptor (GH-R) status is regulated by $\mathrm{GH}$ itself (24). In GHD, many authors reporting contrasting results $(19,24-29)$ have studied $\mathrm{GH}$ binding protein (GHBP) levels as a marker of GH-R status. The existence of peripheral hypersensitivity to $\mathrm{GH}$ in patients with severe GHD (present data) agree with data by Roelen et al. (27) and Florkowski et al. (28) reporting increased GHBP levels in severe GHD during rhGH replacement. On the other hand, other authors have found that GHBP levels are reduced or unchanged $(19,24-26,29)$.

In contrast with normal subjects, our results show that there is no gender-related difference in the IGF-I response to rhGH in GHD patients. This finding is noteworthy considering that hypopituitary women need a higher rhGH dose than men for optimal IGF-I response and clinical benefit $(19,30,31)$, according to the inhibitory influence of estradiol on IGF-I synthesis and release $(32,33)$. However, our hypopituitary women were on transdermal estradiol replacement and there is already evidence that the negative influence of estradiol on IGF-I synthesis and release depends on the method of administration as well as on the estrogenic dose in both normal and GHD patients $(34,35)$. On the other hand, in the present experimental conditions, the existence of an enhanced $\mathrm{GH}$ sensitivity in our patients may mask the evidence of a gender-related difference in the IGF-I response to rhGH with the GH doses employed. To demonstrate a genderrelated difference, testing with a rhGH dose lower than $1.25 \mu \mathrm{g} / \mathrm{kg}$ would be helpful. Moreover, the possibility has to be considered that the lack of a sex-related difference is limited to the first days of treatment and that it could become apparent later on. We are now studying the long-term effect of $0.625,1.25,2.5$ and $5.0 \mu \mathrm{g} / \mathrm{kg} /$ day $\mathrm{rhGH}$ doses in GHD patients of both sexes. Finally, the small number of patients studied limited the finding of a lack of a gender-related difference.

In agreement with other authors, our data further indicate that IGFBP-3 is a less sensitive marker of $\mathrm{GH}$ 


\section{Normal Volunteers}

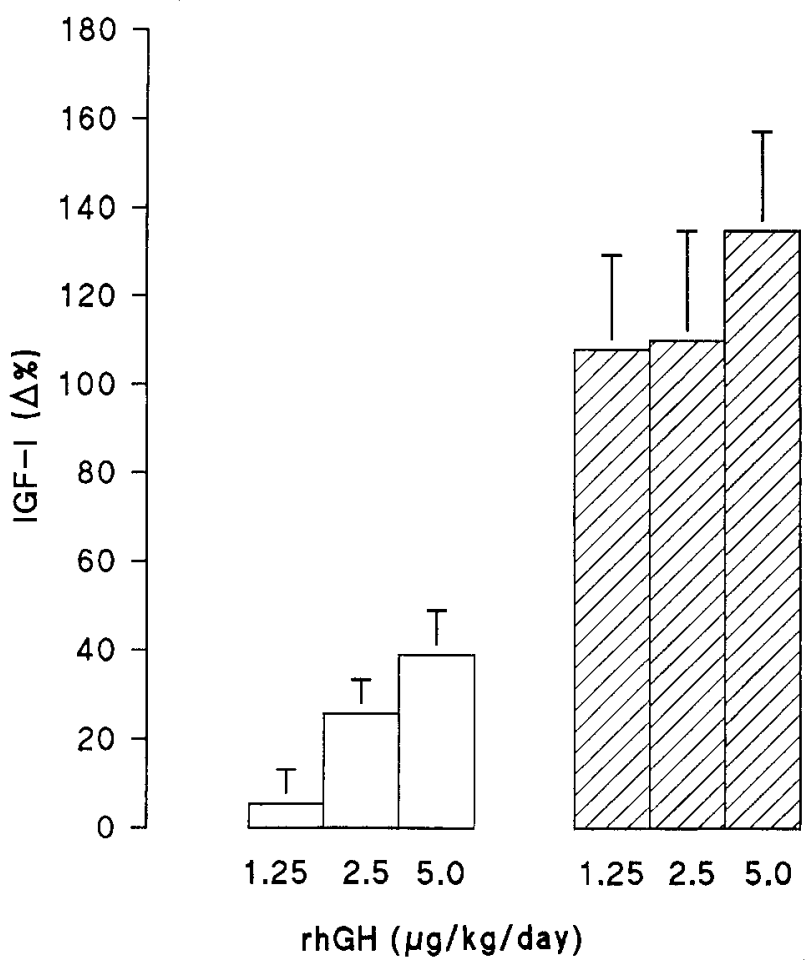

Figure 3 IGF-I $\Delta$ percentage increases (mean \pm S.E.) above baseline after $1.25,2.5$ and $5.0 \mu \mathrm{g} / \mathrm{kg} / \mathrm{day} \mathrm{rhGH}$ in 21 normal volunteers and in $25 \mathrm{GHD}$ patients.

status than is IGF-I $(36,37)$ and it is also less sensitive than IGF-I to rhGH stimulation $(8,10,21)$. In spite of this, GHD patients showed a significant increase in IGFBP-3 levels with rhGH doses which were ineffective in normal subjects. As IGFBP-3 synthesis and release depend not only on GH but also on IGF-I $(4,38)$, the enhanced IGFBP-3 sensitivity in GHD patients could also depend on the higher increases in IGF-I, at variance with normal volunteers.

In conclusion, the present study demonstrates that the IGF-I and IGFBP-3 responses to very low doses of GH are enhanced in GHD compared with normal subjects, at least after very short-term treatment. This evidence suggests the existence of enhanced peripheral GH sensitivity in GH deprivation.

\section{Acknowledgements}

This study was performed under the auspices of the Italian Society of Endocrinology, Study Group 'Pathophysiology of GH Secretion' and was supported in part by grants from NOVO-NORDISK (Rome, Italy), Ministero Università e Ricerca Scientifica e Tecnologica (Rome, Italy) and Fondazione Studio Malattie EndocrinoMetaboliche (Turin, Italy). The authors wish to thank Mrs M Taliano for her skilful technical assistance.

\section{References}

1 Underwood LE \& Van Wyk JJ. Normal and aberrant growth. In Williams Textbook of Endocrinology, 8th edn, p 1079. Eds JD Wilson \& DW Foster. Philadelphia: Saunders \& Co., 1992.

2 Veldhuis JD. New modalities for understanding dynamic regulation of the somatotropic (GH) axis: explication of gender differences in GH neuroregulation in the human. Journal of Paediatric Endocrinology and Metabolism 19969 237-253.

3 Blum WF, Albertsson-Wikland K, Rosberg S \& Ranke MB. Serum levels of insulin-like growth factor-I (IGF-I) and IGF binding protein-3 (IGFBP-3) reflect spontaneous growth hormone secretion. Journal of Clinical Endocrinology and Metabolism $1993 \mathbf{7 6}$ 1610-1616.

4 Thissen J-P, Ketelslegers J-M \& Underwood LE. Nutritional regulation of the insulin-like growth factors. Endocrine Review $19941580-81$.

5 Aimaretti G, Corneli G, Razzore P, Bellone S, Baffoni C, Bellone J et al. Usefulness of IGF-I assay for the diagnosis of GH deficiency in adults. Journal of Endocrinological Investigation 1998 21 506-511.

6 Hoffman DM, O'Sullivan AJ, Baxter RC \& Ho KY. Diagnosis of growth hormone deficiency in adults. Lancet 1994 i 10641068.

7 Ghigo E, Aimaretti G, Gianotti L, Bellone J, Arvat E \& Camanni F. New approach to the diagnosis of growth hormone deficiency in adults. European Journal of Endocrinology 1996134 352-356.

8 Svensson J, Johannsson G \& Bengtsson BA. Insulin-like growth factor-I in growth hormone-deficient adults: relationship to population-based normal value, body composition and insulin tolerance test. Clinical Endocrinology 199746 579-586.

9 de Boer H, Blok GJ \& van Der Veen EA. Clinical aspects of growth hormone deficiency in adults. Endocrine Review 199516 63-86.

10 de Boer H, Blok GJ, Popp-Snjders C, Stuurman L, Baxter RC \& Van der Veen EA. Monitoring of growth hormone replacement therapy in adults, based on measurement of serum marker. Journal of Clinical Endocrinology and Metabolism 199681 13721377.

11 The Growth Hormone Research Society Group. Consensus guidelines for diagnosis and treatment of adults with GH deficiency. Journal of Clinical Endocrinology and Metabolism 1998 83 379-381.

12 Jorgensen JO, Pedersen SA, Thuesen L, Jorgensen J, IngemannHansen T, Skakkebaek NE et al. Beneficial effects of growth hormone treatment in GH-deficient adults. Lancet 1989 i $221-$ 225.

13 Salomon F, Cuneo RC, Hesp RC \& Sonksen PH. The effects of treatment with recombinant human growth hormone on body composition and metabolism in adults with growth hormone deficiency. New England Journal of Medicine 1989321 19791983.

14 Cuneo RC, Salomon F, Mark Wiles C, Hesp RC \& Sonksen PH. Growth hormone treatment in growth hormone deficient adults. II. Effects on exercise performance. American Journal of Physiology 199170 695-700.

15 Amato G, Carella C, Fazio S, La Montagna G, Cittadini A, Sabatini D et al. Body composition, bone metabolism and heart structure and function in growth hormone $(\mathrm{GH})$ deficient adults before and after GH replacement therapy at low doses. Journal of Clinical Endocrinology and Metabolism 199377 1671-1676.

16 Merola B, Cittadini A, Colao A, Longobardi S, Fazio S, Sabatini D et al. Cardiac structural and functional abnormalities in adult patients with growth hormone deficiency. Journal of Clinical Endocrinology and Metabolism 199377 1658-1661.

17 Cittadini A, Cuocolo A, Merola B, Fazio S, Sabatini D, Nicolai E et al. Impaired cardiac performance in GH-deficient adults and its improvement after GH replacement. American Journal of Physiology (Endocrinology and Metabolism) 1994267 E219-E225.

18 Rosen $\mathrm{T} \&$ Bengtsson BA. Premature mortality due to cardiovascular disease in hypopituitarism. Lancet $1990 \mathbf{3 3 6}$ 285-288. 
19 Johannsson G, Bjarnason R, Bramnert M, Carlsson LM, Degerblad M, Manhem P et al. The individual responsiveness to growth hormone $(\mathrm{GH})$ treatment in $\mathrm{GH}$-deficient adults is dependent on the level of GH-binding protein, body mass index, age and gender. Journal of Clinical Endocrinology and Metabolism $1996811575-1581$.

20 de Boer H \& van der Veen EA. Guidelines for optimising growth hormone replacement therapy in adults. Hormone Research 1997 48 (Suppl 5) 21-30.

21 Ghigo E, Aimaretti G, Maccario M, Fanciulli G, Arvat E, Minuto F et al. Dose-response study of $\mathrm{GH}$ effects on circulating IGF-I and IGFBP-3 levels in healthy young men and women. American Journal of Physiology (Endocrinology and Metabolism) 1999276 E1009-E1013.

22 Aimaretti G, Corneli G, Razzore P, Bellone S, Baffoni C, Arvat E et al. Comparison between insulin induced hypoglycaemia and growth hormone $(\mathrm{GH})$-releasing hormone+arginine as provocative tests for the diagnosis of GH deficiency. Journal of Clinical Endocrinology and Metabolism 199883 1615-1618.

23 Lucidi P, Lauteri M, Laureti S, Celleno R, Santoni S, Volpi E et al. A dose-response study of growth hormone $(\mathrm{GH})$ replacement on whole body protein and lipid kinetics in GH-deficient adults. Journal of Clinical Endocrinology and Metabolism 199883 353357.

24 Baumann G, Shaw MA \& Amburn K. Circulating growth hormone binding proteins. Journal of Endocrinological Investigation $19941767-81$.

25 Martha PM Jr, Reiter EO, Davila N, Shaw MA, Holcombe JH \& Baumann G. Serum growth hormone (GH)-binding protein/ receptor: an important determinant of GH responsiveness. Journal of Clinical Endocrinology and Metabolism 199275 1464-1469.

26 Davila N, Alcaniz J, Salto L, Estrada N, Barcelo B \& Baumann G. Serum growth hormone-binding protein is unchanged in adult panhypopituitarism. Journal of Clinical Endocrinology and Metabolism 199479 1347-1350.

27 Roelen CA, Koppeschaar HP, de Vries WR, Doerga ME, Snel YE, Bol E et al. High-affinity growth hormone $(\mathrm{GH})$ binding protein (GHBP), and insulin-like growth factor binding protein-3 predict the GHBP response to $\mathrm{GH}$ therapy in adult $\mathrm{GH}$ deficiency syndrome. Metabolism $1999 \mathbf{4 8} 314-318$.

28 Florkowski CM, Barnard R, Livesey JH, Veveris T, Espiner EA \& Donald RA. Growth hormone binding protein correlates strongly with leptin and percentage of body fat in GH-deficient adults, is increased by GH replacement but does not predict IGF-I response. Growth Hormone and IGF Research 19999 35-40.
29 Roelen CA, Koppeschaar HP, de Vries WR, Zelissen PM, Snel YE, Doerga ME et al. High-affinity growth hormone binding protein, insulin-like growth factor I and insulin-like growth factor binding protein 3 in adults with growth hormone deficiency. European Journal of Endocrinology 1996135 82-86.

30 Burman P, Johansson AG, Siegbahn A, Vessby B \& Karlsson FA. Growth hormone $(\mathrm{GH})$ deficient men are more responsive to $\mathrm{GH}$ replacement therapy than women. Journal of Clinical Endocrinology and Metabolism 199781 550-555.

31 Johansson AG, Engstrom BE, Ljunghall S, Karlsson FA \& Burman P. Gender differences in the effects of long term growth hormone $(\mathrm{GH})$ treatment on bone in adults with $\mathrm{GH}$ deficiency. Journal of Clinical Endocrinology and Metabolism $1999842002-$ 2007.

32 Kelly J, Rajkovic IA, O'Sullivan AJ, Sernia C \& Ho KKY. Effects of different oral oestrogen on insulin-like growth factor I, growth hormone binding protein in post menopausal women. Clinical Endocrinology $199339516-517$.

33 Weissberger AJ, Ho KKY \& Lazarus L. Contrasting effects of oral and transdermal routes of estrogen replacement therapy on 24-h growth hormone $(\mathrm{GH})$ secretion, insulin-like growth factor I and GH-binding protein in postmenopausal women. Journal of Clinical Endocrinology and Metabolism 199172 374-381.

34 Cook DM, Ludlam WH \& Cook MB. Route of estrogen administration helps to determine growth hormone $(\mathrm{GH})$ replacement dose in GH-deficient adults. Journal of Clinical Endocrinology and Metabolism 199984 3956-3960.

35 Friend KE, Hartman ML, Pezzoli SS, Clasey JL \& Thorner MO. Both oral and transdermal estrogen increase growth hormone release in postmenopausal women - a clinical research study. Journal of Clinical Endocrinology and Metabolism $1996812250-$ 2256.

36 Blum WF \& Ranke MB. Use of insulin-like growth factor-binding protein 3 for the evaluation of growth disorders. Hormone Research 199033 (Suppl 4) 31-37.

37 Clemmons DR \& Van Wyk JJ. Factors controlling blood concentration of somatomedin C. Journal of Clinical Endocrinology and Metabolism 199413 113-118.

38 Corpas E, Hartman SM \& Blackman S. Human growth hormone and human aging. Endocrine Review 199314 20-39.

Received 17 January 2001

Accepted 4 May 2001 